\title{
Pengaruh Pemberian Minuman Cokelat (Theobroma cacao L.) Terhadap Berat Basah Organ Hati Tikus Diabetes Melitus
}

\author{
Putri Rahayu Ratri ${ }^{1}$, Adhiningsih Yulianti ${ }^{2}$, Arisanty Nur Setia Restuti ${ }^{3}$ \\ ${ }^{1)}$ Program Studi Gizi Klinik, Jurusan Kesehatan, Politeknik Negeri Jember,putri_ratri@polije.ac.id \\ ${ }^{2)}$ Program Studi Gizi Klinik, Jurusan Kesehatan, Politeknik Negeri Jember, adhiningsih@polije.ac.id \\ 3) Program Studi Gizi Klinik, Jurusan Kesehatan, Politeknik Negeri Jember, arisanty@ polije.ac.id
}

\begin{abstract}
ABSTRAK
Kakao (Theobroma cacao L.) diketahui memiliki potensi yang sangat besar karna mengandung vitamin A1, B1, B2, $C$, D, dan E serta mineral seperti zat besi, zinc, fosfor, magnesium, dan tembaga. Selain itu, cokelat juga kaya bahan aktif antioksidan seperti senyawa fenolik, prociandin, dan flavonoid yang mampu meredam efek buruk antioksidan di dalam tubuh. Pemberian cokelat pada hewan coba maupun intervensi konsumsi pada manusia mampu mencegh dan mengatasi masalah beberapa penyakit salah satunya diabetes melitus. Tujuan dari penelitian ini adalah melihat pengaruh dari pemberian minuman bubuk cokelat terhadap berat basah organ hati tikus diabetes melitus. Desain penelitian yang digunakan adalah penelitian eksperimental menggunakan Rancangan Acak Lengkap dengan desain post test only control group. Sampel percobaan menggunakan lima belas tikus putih (Rattus norvegicus) jantan galur Sprangue Dawley. Tikus percobaan tersebut dibagi menjadi 5 kelompok yaitu kelompok kontrol negatif (K-) yaitu tikus normal tanpa perlakuan apapun, kelompok positif yaitu kelompok tikus diabetes melitus (K+); kelompok perlakuan 1 (KP1), kelompok perlakuan 2 (KP2), kelompok perlakuan 3 (KP3) yaitu kelompok tikus diabetes melitus yang diberikan perlakuan minuman cokelat dengan konsentrasi minuman bubuk cokelat dosis 2\%, 4\% dan 6\%. Analisis data dilakukan menggunakan uji One Way ANOVA. Hasil penelitian menunjukan berat organ pada kelompok $K-=10,46 \pm 0,44 ; K+=11,49 \pm 0,39 ; K P 1=9,95 \pm 0,60 ; K P 2=11,30 \pm 0,60 ; K P 3=11.09 \pm 0,90$. Analisis statistik menunjukan bahwa tidak adanya perbedaan signifikan tiap perlakuan dengan nilai $p=0,077$. Kesimpulan pada penelitian mengenai pengaruh pemberian minuman cokelat terhadap berat basah organ hati tikus diabetes melitus menunjukan bahwa pemberian minuman bubuk cokelat dengan konsentrasi 2\%, 4\% dan 6\% belum mampu memengaruhi berat basah organ hati secara signifikan.
\end{abstract}

Kata kunci: cokelat, berat basah hati, diabetes melitus

\begin{abstract}
Cacao (Theobroma cacao L.) is known to have enormous potential advantages because they contain vitamins A1, B1, $B 2, C, D$, and $E$ as well as minerals such as iron, zinc, phosphorus, magnesium, and copper. In addition, chocolate is also known to be rich in active antioxidant ingredients such as phenolic compounds, prociandin, and flavonoids which can reduce the bad effects of antioxidants in the body. giving chocolate to experimental animals and consumption interventions in humans can prevent and overcome the problem of several diseases, one of which is diabetes mellitus. The purpose of this study was to see the effect of giving cocoa powder drink to the wet weight of the liver in rats with diabetes mellitus. The research design used was experimental research using a completely randomized design with a post-test only control group design. The experimental sample used fifteen male white rats (Rattus norvegicus) Sprague Dawley strain. The experimental mice were divided into 5 groups, namely the negative control group (K-), namely normal rats without any treatment, the positive group, namely the diabetes mellitus $(K+)$ group; treatment group 1 (KP1), treatment group 2 (KP2), treatment group 3 (KP3), namely the diabetes mellitus group of rats that were given the treatment of chocolate drink with a concentration of cocoa powder drink doses of $2 \%, 4 \%$ and $6 \%$. Data analysis was performed using the One Way ANOVA test. Results: The results showed that the organ weight in the group K-= $10.46 \pm 0.44 ; \mathrm{K}+=11.49 \pm 0.39 ; \mathrm{KP} 1=9.95 \pm 0.60 ; \mathrm{KP} 2=11.30 \pm 0.60 ; \mathrm{KP} 3=11.09 \pm 0.90$. Statistical analysis showed that there was no significant difference for each treatment with a value of $p=0.077$. The conclusions in the study regarding the effect of giving chocolate drink on the wet weight of the liver in rats with diabetes mellitus showed that giving cocoa powder with a concentration of $2 \%, 4 \%$ and $6 \%$ was not able to significantly affect the wet weight of the liver.
\end{abstract}

Keywords: chocolate, liver weight, diabetes melitus

* Korespondensi Author : Putri Rahayu Ratri, Politeknik Negeri Jember, putri_ratri@polije.ac.id, +6821384105501 


\section{PENDAHULUAN}

Indonesia merupakan salah satu negara yang memiliki kepadatan penduduk yang cukup tinggi. Hasil survey Badan Pusat Statistik Indonesia pada tahun 2020 menunjukan jumlah penduduk Indonesia pada tahun 2019 adalah 268.074.600 jiwa dengan laju pertumbuhan penduduk sebesar $1,31 \%$ terhitung sejak 20102019. ${ }^{1}$ Meningkatnya jumlah penduduk tiap tahunnya menyebabkan kebutuhan akan nutrisi yang semakin tinggi. Ketahanan pangan yang stabil harus selalu diupayakan agar selalu tercipta kesejahteraan sosial., ${ }^{2,3}$

Berbagai cara dilakukan untuk dapat menciptakan ketahanan pangan salah satunya adalah mengembangkan pangan fungsional dengan memanfaatkan potensi dari sumber daya pangan lokal. Pengembangan pangan fungsional bukan hanya menitikberatkan pada kandungan zat gizi namun juga eksplorasi dan pengembangan potensi zat non gizi seperti komponen bioaktif. Komponen bioaktif tersebut diketahui mampu memberikan efek menyehatkan dan dapat mencegah penyakit tertentu. Salah satu bahan pangan lokal yang memiliki potensi cukup besar adalah cokelat (Theobroma cacao). ${ }^{3}$

Biji cokelat diketahui memiliki potensi yang sangat besar karna mengandung vitamin A1, B1, B2, C, D, dan E serta mineral seperti zat besi, zinc, fosfor, magnesium, dan tembaga. Selain itu cokelat juga kaya bahan aktif antioksidan seperti senyawa fenolik, prociandin, dan flavonoid yang mampu meredam efek buruk antioksidan di dalam tubuh. ${ }^{3,4}$ Beberapa hasil penelitian menunjukan bahwa biji kakao memiliki kandungan flavonol monomerik seperti katekin dan epikatekin serta flavonol oligomerik (prociandin) yang diketahui mampu menyediakan pertahanan terhadap aktivitas Reactive Oxygen Species (ROS). ${ }^{4}$ Menurut Kelishadi (2005) cokelat memiliki nilai ORAC (Oxygen Reactive Species Capacity) hingga 13.120 unit/100 gram. Angka tersebut merupakan nilai tertinggi bila dibandingkan dengan produk pangan fungsional dari bahan alam lain seperti kelompok buah beri, kale, raisin, bayam, brokoli, alfalfa, anggur, jeruk, ceri, bawang merah, jagung, dan terong. ${ }^{5}$

Beberapa penelitian menunjukan bahwa pemberian cokelat pada hewan coba maupun intervensi konsumsi pada manusia mampu mencegah dan mengatasi masalah beberapa penyakit salah satunya diabetes melitus. Seperti penelitian yang dilakukan Grassi et al. (2004) menggunakan sampel manusia sehat menunjukan bahwa pemberian dark cokelat pada mampu meningkatkan sensitifitas dan resistensi insulin. ${ }^{6}$ Jalil et al. (2008) melakukan penelitian mengenai pengaruh ekstrak cokelat terhadap glukometabolisme, stress oksidatif dan enzim oksidasi pada tikus obes-diabetes. Hasil penelitiannya menunjukkan bahwa suplementasi ekstrak kakao berpengaruh terhadap pengendalian glukosa post prandial tetapi tidak untuk jangka panjang (4 minggu). Selain itu, suplementasi kakao dapat mengurangi asam lemak bebas plasma yang bersirkulasi dan 8-isoprostane serta dapat meningkatkan sistem pertahanan antioksidan. ${ }^{7}$

Penelitian Marco et al. (2014) menunjukan bahwa pemberian bubuk cokelat mampu menormalkan berat badan mencit diabetes melitus ${ }^{8}$. Selanjutnya penelitian eksperimental yang dilakukan oleh Olasope et al. (2016) menunjukan bahwa bubuk cokelat mampu berperan sebagai agen anti diabetes dengan percobaan pada tikus diabetes melitus selama tiga minggu. Hasil penelitiannya menunjukan bahwa bubuk kakao dapat meningkatkan berat badan serta dapat menurunkan kadar gukosa darah tikus diabetes melitus yang diinduksi aloksan. ${ }^{9}$

Berdasarkan penelitian-penelitian diatas dapat diketahui bahwa kakao dan olahan cokelat kaya akan senyawa antioksidan yang bermanfaat bagi kesehatan, namun dalam pemanfaatannya diperlukan kajian yang luas dan mendalam untuk mengetahui mekanisme, dosis, dan cara konsumsi yang tepat yang tepat dalam mencegah dan mengatasi masalah kesehatan seperti penyakit metabolisme khususnya diabetes melitus. Oleh karena itu, penelitian ini bertujuan untuk melihat pengaruh pemberian minuman cokelat dengan berbagai dosis terhadap berat basah organ hati tikus diabetes melitus. Penelitian ini merupakan salah satu langkah yang diharapkan mampu memberikan kontribusi dalam upaya mendukung kesejahteraan dan ketahanan pangan lokal. 


\section{METODOLOGI}

Desain penelitian yang digunakan adalah penelitian eksperimental menggunakan Rancangan Acak Lengkap dengan desain post test only control group. Variabel bebas dalam penelitian ini adalah pemberian minuman cokelat, sedangkan Variabel tergantung dalam penelitian ini adalah berat basah organ hati/hepar. Sampel penelitian menggunakan hewan coba berupa lima belas tikus putih (Rattus norvegicus) jantan galur Sprangue Dawley. Penelitian ini dilakukan di laboratorium biomedik Program Studi Gizi Klinik Polteknik Negeri Jember dan di Laboratorium Biomedik Fakultas Kedokteran Gigi Universitas Jember,

Tikus percobaan tersebut kemudian dibagi menjadi 5 kelompok yaitu kelompok kontrol negatif (K-) yaitu tikus normal tanpa perlakuan apapun, kelompok positif yaitu kelompok tikus diabetes melitus (K+); kelompok perlakuan 1 (KP1), kelompok perlakuan 2 (KP2), kelompok perlakuan 3 (KP3) yaitu kelompok tikus diabetes melitus yang diberikan perlakuan minuman cokelat dengan konsentrasi minuman bubuk cokelat dosis $2 \%, 4 \%$ dan 6\%. Empat kelompok tikus model diabetes melitus (K+, KP1, KP2, KP3) diperoleh dengan cara pemberian pakan HFD (High Fat Diet) dengan komposisi 50\% Rat Bio, 25\% Tepung terigu, 2\% Kolesterol, 5\% minyak babi selama 6 minggu lalu ditambahkan dengan perlakuan injeksi streptozotocin (STZ) dengan dosis $30 \mathrm{mg} / \mathrm{kg}$ BB secara intraperitoneal.

Bubuk kakao yang digunakan pada penelitian ini berasal dari Pusat Penelitian Kopi dan Kakao Indonesia (Indonesian Coffee and Cocoa Research Institute / ICCRI) yang ada di kabupaten Jember Propinsi Jawa Timur. Bubuk kakao yang digunakan berasal dari bungkil kakao yang digiling kemudian disaring hingga mendapatkan ukuran seragam 95-110 mikron. Bubuk kakao kemudian dibuat minuman dengan cara melarutkan dengan air matang tanpa tambahan apapun dan dibuat menjadi konsentrasi $2 \%, 4 \%$, dan 6\%. ${ }^{9}$ Pemberian minuman cokelat diberikan 1 kali/hari selama 14 hari.

Cara membuat larutan minuman bubuk kakao $2 \%, 4 \%$ dan $6 \%$ adalah sebagai berikut:

a) Larutan minuman kakao $2 \%$ dengan cara melarutkan 4 gr bubuk kakao dalam $30 \mathrm{ml}$ air mendidih, setelah kemudian disondekan $3 \mathrm{ml} /$ tikus/ hari. b) Larutan minuman kakao $4 \%$ dengan cara melarutkan 8 gr bubuk kakao dilarutkan dalam $30 \mathrm{ml}$ air mendidih, kemudian disondekan $3 \mathrm{ml} /$ tikus/ hari.

c) Larutan minuman kakao $6 \%$ dengan cara melarutkan 12 gr bubuk kakao dilarutkan dalam $40 \mathrm{ml}$ air mendidih, kemudian disondekan $4 \mathrm{ml} /$ tikus/ hari

Setelah pemberian minuman cokelat terhadap tikus diabetes selama 14 hari lalu tikus dieuthanasia dengan metode dislokasi serviks kemudian dilakukan isolasi organ hati. Organ hati atau hepar yang telah diisolasi kemudian dicuci dengan larutan fisiologis dan ditimbang.

Data yang berskala rasio seperti berat organ basah ditampilkan dalam bentuk mean dan standar deviasi. Analisis univariat dan bivariat diuji menggunakan software SPSS 22. Uji homogenitas untuk melihat normalitas distribusi data menggunakan uji Saphiro Wilk. Nilai p > 0,05 maka data berdistribusi normal, sehingga digunakan Uji one-way ANOVA. Uji One-way ANOVA digunakan untuk melihat secara umum berat badan tikus didalam kelompok dan antar kelompok. Alur kerja pada metode penelitian dapat dilihat pada gambar 1 . 


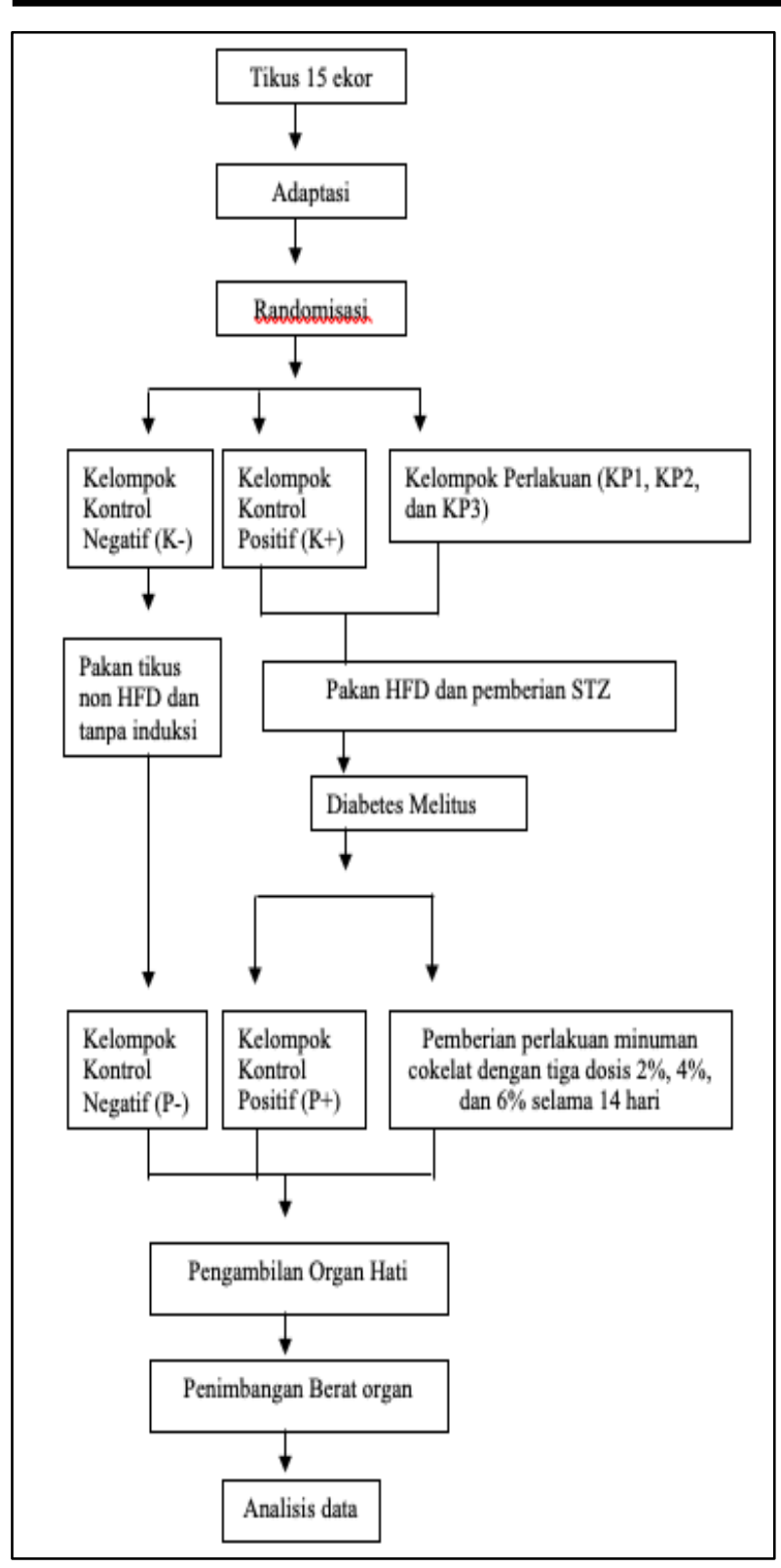

Gambar 1. Alur kerja metode penelitian

\section{HASIL DAN PEMBAHASAN}

Penelitian ini dilakukan dengan menggunakan sampel tikus wistar diabetes melitus. Model diabetes melitus dilakukan dengan cara pemberian pakan High Fat Diet (HFD). Pakan tinggi kalori dan lemak diketahui dapat memicu terjadinya gangguan pada metabolisme glukosa dalam tubuh pada hewan coba. Kadar glukosa dalam darah yang tinggi secara terus menerus akan memicu terjadinya resistensi insulin. Akibatnya sel target insulin seperti otot yang bertugas memetabolisme glukosa idak mampu merespon keberadaan insulin. Selain itu pakan HFD yang tinggi kadar lemak akan memicu tingginya kadar asam lemak bebas dalam darah. Tingginya kadar lemak bebas dalam darah dapat memicu peningkatan aktivitas Reactive oxygen species (ROS) / stress oksidatif yang memicu pengaktifan kaskade sinyaling kinase serin/treonin multiple. Kinase tersebut dapat merusak proses persinyalan hormon insulin dengan meningkatkan fosforilasi serin yang bersifat menghambat insulin receptor substrate (IRS). ${ }^{9-12}$

Selain pemberian pakan HFD, tikus model diabetes melitus juga diinduksi oleh injeksi Streptozotocin (STZ) dengan dosis $30 \mathrm{mg} / \mathrm{kg}$ bb secara intraperitoneal. Menurut Nugroho (2006) induksi STZ dapat memprofile metabolisme diabetes melitus tipe 2 pada tikus ${ }^{13}$. STZ merupakan senyawa 2-deoxy-2-(3-(methyl-3nitrosoureido) - $D$ glucopyranose yang dapat merusak DNA pada inti sel $\beta$ pankreas. Perubahan yang terjadi pada sel $\beta$ pankreas akibat induksi STZ dapat menyebabkan disfungsi pankreas dalam sekresi insulin. ${ }^{13,14}$

Tikus model diabetes melitus kemudian diberikan perlakuan pemberian minuman cokelat dengan dosis berbeda $(2 \%, 4 \%$, dan $6 \%)$ dan dilihat pengaruhnya terhadap berat basah organ hati/hepar. Data rerata berat basah organ hati tiap kelompok perlakuan dapat dilihat pada Tabel 1 .

Tabel 1. Rerata berat basah organ hepar

\begin{tabular}{lccc}
\hline Perlakuan & $\begin{array}{l}\text { Mean } \\
(\mathrm{g} / \mathrm{dl})\end{array}$ & $\begin{array}{c}\text { Standar } \\
\text { Deviasi }\end{array}$ & $\mathrm{P}$ \\
\hline $\begin{array}{l}\text { Kontrol Negatif } \\
\text { Kontrol Positif }\end{array}$ & 10,46 & 0,44 & \\
$\begin{array}{l}\text { Perlakuan 1 } \\
\text { (Minuman bubuk }\end{array}$ & 9,49 & 0,39 & \\
$\begin{array}{l}\text { cokelat 2\%) } \\
\text { Perlakuan 2 } \\
\text { Minuman bubuk }\end{array}$ & 11,30 & 0,60 & \\
cokelat 4\%) & & & 0,077 \\
$\begin{array}{l}\text { Perlakuan 3 } \\
\text { Minuman bubuk } \\
\text { cokelat 6\%) }\end{array}$ & 11,09 & 0,90 & \\
\hline $\begin{array}{l}\text { Uji One Way ANOVA dengan } \mathrm{p}<\alpha(\alpha=0,05) \\
\text { menunjukkan signifikan }\end{array}$ & &
\end{tabular}

Berat basah organ hepar digunakan sebagai parameter dalam penelitian ini karena sesuai dengan penelitian Rust (2002) yang menyatakan menyatakan bahwa perubahan bobot, fisiologis, dan morfologis hepar berkaitan dengan pakan yang dikonsumsi, kesehatan, dan asupan zat toksik dalam tubuh hewan. ${ }^{16}$ Wahyuningtyas dkk. (2018) 
menyatakan bahwa kerusakan sel-sel hati umumnya diikuti oleh penurunan atau kenaikan bobot badan serta bobot organ yang signifikan ${ }^{17}$.

Berdasarkan uji One Way ANOVA penelitian diketahui bahwa pemberian minuman cokelat belum mampu memengaruhi berat badan organ tikus secara signifikan. Hal dapat disebabkan oleh kemampuan hati untuk melakukan regenerasi sel. Kerusakan hati yang sifatnya degeneratif dapat bersifat reversible dimana sel hati dapat kembali ke struktur normal sehingga menyebabkan tidak adanya perbedaan yang signifikan pada berat basah organ hati tikus pada tiap kelompok perlakuan. ${ }^{18,19}$

Sel-sel hepatosit pada hepar merupakan sel yang mempunyai aktivitas tinggi, sehingga mudah rusak, namun juga mempunyai sifat mudah beregenerasi dengan cara mitosis untuk menggantikan sel yang rusak. ${ }^{19}$ Oleh karena itu diperlukan penelitian lebih lanjut dengan penambahan waktu pemberian perlakuan agar efek perbaikan dari senyawa antioksidan yang terdapat dalam kakao dapat terlihat secara signifikan.

Walaupun berdasarkan analisis statistik yang menunjukan tidak adanya perbedaan yang signifikan antar perlakuan, namun dapat dilihat pada Tabel 1 bahwa nilai rerata berat basah organ hati tidak pada kelompok perlakuan kotrol positif (tikus diabetes melitus yang tidak diberikan minuman cokelat) menunjukan angka rerata tertinggi $(11,49 \pm 0,39)$ sedangkan nilai rerata kelompok tikus yang diberikan perlakuan minuman cokelat berada di bawah nilai rerata kelompok kontrol positif $(\mathrm{KP} 1=9.95 \pm 0.60 ; \mathrm{KP} 2=11.30 \pm$ $0.60 ; \mathrm{KP} 3=11.09 \pm 0.90)$. Fenomena tersebut kemungkinan terjadi karena pada kelompok kontrol positif sel-sel hati mulai mengalami pembengkakan. Kerusakan sel hepatosit dimulai dengan adanya pembengkakan sel yang kemudian diikuti oleh kejadian atrofi dan nekrosis ${ }^{19}$. Hal tersebut juga menjelaskan pada kelompok tikus yang diberikan minuman cokelat dengan dosis $6 \%$ menunjukan penurunan berat berat organ. Kemungkinan dosis $6 \%$ memberikan efek yang lebih baik dari dosis $4 \%$.

Penurunan berat organ pada kelompok perlakuan yang diberikan minuman cokelat mendekati nilai rerata berat organ hati pada kelompok kontrol negatif kemungkinan dikarenakan adanya aktifitas dari senyawa antioksidan yagg terkandung dalam minuman cokelat (senyawa flavonoid) yang mampu meredam efek buruk dari adanya ROS / stres oksidatif. Penelitian oleh Agata dkk (20016) menunjukan bahwa senyawa antioksidan flavonoid dalam daun sirsak mampu memengaruhi berat organ hati secara signifikan ${ }^{20}$. Sebagai tambahan bukti manfaat antioksidan dalam kakao adalah penelitian sebelumnya yang telah dilakukan oleh Restuti dkk pada tahun 2018 yang membuktikan bahwa senyawa antioksidan flavonoid yang terkandung dalam bubuk kakao dapat menurunkan gula darah puasa tikus diabetes melitus. ${ }^{21}$

\section{SIMPULAN DAN SARAN}

Simpulan pada penelitian mengenai pengaruh pemberian minuman cokelat terhadap berat basah organ hati tikus diabetes melitus menunjukan bahwa pemberian minuman bubuk cokelat dengan konsentrasi $2 \%, 4 \%$ dan $6 \%$ belum mampu berpengaruh terhadap berat basah organ hati secara signifikan $(p=0,077)$. Oleh karena itu peneliti menyarankan perlu dilakukannya penelitian lebih lanjut secara mendalam mengenai efek minuman cokelat terhadap pencegahan dan pengobatan diabetes melitus. Penelitian mendalam yang disarankan dari sisi pengaruhnya terhadap organ-organ lain yang berperan dalam metabolisme seperti pankreas, ginjal, dan sebagainya. Penelitian dengan parameter histologis organ maupun molekular (analisis gen dan protein yang berperan) juga perlu dilakukan untuk mendapatkan data pendukung penegakan dosis dan cara konsumsi yang tepat.

\section{TERIMA KASIH}

Ucapan terima kasih disampaikan kepada DIPA Politeknik Negeri Jember atas pendanaan hibah PNBP sesuai dengan SP DIPA-023.18.2.677607/2020, Tanggal 27 Desember 2019, Tahun Anggaran 2020.

\section{REFERENSI}

1. Badan Pusat Statistik Indonesia. Statistik Indonesia 2020. Badan Pusat Statistik. Jakarta; 2020.

2. Rivani E. Penentuan Dimesi Serta Indikator Ketahanan Pangan Di Indonesia : Kaji Ulang Metode Dewan Ketahanan Pangan-World Food Program. Widyariset. 2010;15(1): 151-162.

3. Ikrawan Y, Hasnelly, Stahrudin D. Sifat 
fungsional dark chocolate yang bergula rendah kalori dengan penambahan green tea dan soy powder. Dalam. Peran ahli teknolog pangan dalam mewujudkan ketahanan pangan nasional. Seminar Nasional Perhimpunan Ahli Teknologi Pangan Indonesia (PATPI). Bandar Lampung: 2017.

4. Sudibyo A. Peran cokelat sebagai produk pangan derivate kakao yang menyehatkan. Jurnal Riset Industri. 2012; 6(1): 23-40.

5. Kelishadi, RMD. Cacao to Cocoa to Chocolate : Healthy Food? ARYA Journal. 2005; 1(1): 28 34.

6. Grassi, D., Lippi, S., Nicozione, S., Desideri, G. \& Ferri, C. Short-term administration of dark chocolate is followed by significant increase in insulin sensitivity and a decrease in blood pressure in healthy persons. American Journal of Clinical Nutrition. 2004; 81: 611 - 614.

7. Jalil AMH, Ismail A, Pei CP, Hamid M, Kamaruddin SHS. Effect of CocoExtract on Glucometabolism, Oxidative Stress, and Antioxidant Enzymes in Obese-Diabetic (Ob-Db) Rats. Journal of Agricultural and Food Chemistry. 2008; 56(17),

8. Marco Fidaleo, Anna Fracassi, Antonio Zuorro, Roberto Lavecchia, Sandra Moreno, Claudia Sartori. Cocoa protective effects against abnormal fat storage and oxidative stress induced by a high fat diet involve PP ARa signaling activation. Food Funct. 2014;5:2931-2939.

9. Olasope, T.M., G.T. Fadupin, O. Olubamiwa, dan C.O. Jayeola. Glucose-lowering Potential of Cocoa Powder Intake - An Avenue for Positive Management of Diabetes Mellitus. British Journal of Medicine and Medical Research, 2016; 16(2): $1-7$.

10. Park J. Increase in Glucose-6-Phosphate Dehydrogenase in Adipocytes Stimulates Oxidative Stress and Inflammatory Sig- nals. Diabetes. 2006; (55):2939-2949.

11. Qatanani M. Mechanisms of obesity-as- sociated insulin resistance: many choices on the menu. Genes \& Development. 2007; (21): 1443- 1455

12. Dewi M. Resistensi Insulin Terkait Obesitas: Mekanisme Endokrin dan Intrinsik Sel. Jurnal Gizi dan Pangan. 2007; 2(2): 49 - 54.

13. Nugroho AE. 2006. Hewan percobaan diabetes mellitus: patologi dan mekanisme aksi diabetogenik. Jurnal Biodiversitas 7(4):378- 382.

14. Kusumawati, D. 2016. Bersahabat dengan Hewan Coba. Yogyakarta: Gadjah mada University Press.

15. King, A.J.F. 2012. The use of Animal Models in Diabetes Research.British Journal of
Pharmacology, nomor 166, halaman 877-894. [serial online]. www.brjpharmacol.org. DOI:10.1111/j.1476-5381.2012.01911.x. [4 juni 2017].

16. Rust, M.B. 2002. Nutritional Physiology. In: Halver, J.E., R.W. Hardy(eds.). Fish nutrition. USA: Academic Press. 2002

17. Wahyuningtyas, P., A. J. Sitasiwi, S. M. Mardiati. 2018. Hepatosomatic Index (HSI) dan Diameter Hepatosit Mencit (Mus musculus L) setelah paparan ekstrak air biji pepaya (Carica papaya $\mathrm{L}$ ). Jurnal Biologi 7 (1): 8- 17.

18. Maulida, A., I. Syafruddin, H. Salomo. Pengaruh Pemberian Vitamin C dan E Terhadap Gambaran Histologis Hepar Mencit (Mus musculus L.) yang Dipajankan Monosodium Glutamat (MSG). Fakultas MIPA, Universitas Sumatera Utara (USU). 2013.

19. Utari, K.D., T .R. Saraswati. 2009. Efek Rebusan Daun T apak Dara pada Dosis dan Frekuensi yang Berbeda terhadap Kerusakan dan Akumulasi Glikogen pada Hepar Mencit (Mus musculus). Jurnal Bioma. 11(1): 1-5.

20. Agata A, Widiastuti EL, Susanto GN, Sutaryoso. Respon Histopatologis Hepar Mencit (Mus musculus) yang diinduksi Benzo ( $\alpha$ ) Piren terhadap Pemberian Taurin dan Ekstrak Daun Sirsak (Annona muricata). Jurnal Natur Indonesia. 2016;16(2): $54-63$.

21. Restuti ANS, Yulianti A, Nuraini N. 2018. Intervensi bubuk kakao (Theobroma caco L. ) terhadap perubahan kadar gula darah puasa tikus Sprague Dawley Diabetes Melitus. Jurnal Riset Kesehatan. 2018:. 7(2): $57-60$. 